\title{
Molecular Investigation on Tick-Borne Hemoparasites and Coxiella burnetii in Dromedary Camels (Camelus dromedarius) in Al Dhafra Region of Abu Dhabi, UAE
}

\author{
El Tigani Ahmed El Tigani-Asil ${ }^{1,+}{ }^{+}$, Valeria Blanda ${ }^{2, *, \dagger}$, Ghada Elderdiri Abdelwahab ${ }^{1}$, \\ Zulaikha Mohamed A1 Hammadi ${ }^{1}$, Shameem Habeeba ${ }^{1}$, Abdelmalik Ibrahim Khalafalla ${ }^{1}$, \\ Mohamed Ali Alhosani ${ }^{1}$, Francesco La Russa $\left.{ }^{2}{ }^{(}\right)$, Sergio Migliore $\left.{ }^{2}{ }^{(}\right)$, Alessandra Torina ${ }^{2}$ (D), \\ Guido Ruggero Loria ${ }^{2}$ and Salama Suhail Al Muhairi ${ }^{1}$
}

1 Abu Dhabi Agriculture and Food Safety Authority (ADAFSA),

Abu Dhabi Emirate 52150, United Arab Emirates; eltigani.mohammed@adafsa.gov.ae (E.T.A.E.T.-A.); Ghada.AbdelWahab@adafsa.gov.ae (G.E.A.); zulaikha.alhammadi@adafsa.gov.ae (Z.M.A.H.); shameem.beevi@adafsa.gov.ae (S.H.); abdelmalik.khalafalla@adafsa.gov.ae (A.I.K.); mohamed.a.alhosani@adafsa.gov.ae (M.A.A.); salama.almuhairi@adafsa.gov.ae (S.S.A.M.)

check for

updates

Citation: El Tigani-Asil, E.T.A.; Blanda, V.; Abdelwahab, G.E.;

Hammadi, Z.M.A.; Habeeba, S.; Khalafalla, A.I.; Alhosani, M.A.; La Russa, F.; Migliore, S.; Torina, A.; et al. Molecular Investigation on Tick-Borne Hemoparasites and Coxiella burnetii in Dromedary Camels (Camelus dromedarius) in Al Dhafra Region of Abu Dhabi, UAE. Animals 2021, 11, 666. https://doi.org/ $10.3390 /$ ani11030666

Academic Editors:

Mohammed Gagaoua, Amira Leila Dib and Elhacene Bererhi

Received: 28 January 2021

Accepted: 24 February 2021

Published: 2 March 2021

Publisher's Note: MDPI stays neutral with regard to jurisdictional claims in published maps and institutional affiliations.

Copyright: (c) 2021 by the authors. Licensee MDPI, Basel, Switzerland. This article is an open access article distributed under the terms and conditions of the Creative Commons Attribution (CC BY) license (https:/ / creativecommons.org/licenses/by/ $4.0 /)$.
2 Istituto Zooprofilattico Sperimentale della Sicilia, Via Gino Marinuzzi 3, 90129 Palermo, Italy; francesco.larussa@izssicilia.it (F.L.R.); sergio.migliore@izssicilia.it (S.M.); alessandra.torina@izssicilia.it (A.T.); guidoruggero.loria@izssicilia.it (G.R.L.)

* Correspondence: valeria.blanda@izssicilia.it

+ These authors contributed equally to this work.

Simple Summary: Dromedary camels (Camelus dromedarius), or Arabian camels, are mainly widespread in arid regions from the east of Asia to the north of Africa. Many species of parasites/arthropods affect camels, including ticks, able to transmit pathogens to animals and humans. Authors investigated the presence of blood parasites in $n=93$ camels with acute clinical signs and in $n=72$ ticks collected from these camels in Al Dhafra region of Abu Dhabi, United Arabian Emirates, through molecular techniques. All the 72 ticks collected were identified as Hyalomma dromedarii species and were found negative for pathogen DNA. DNA investigations on camel blood samples showed a positivity for tick-transmitted pathogens in 15 heads (16.1\%): 15 Anaplasma phagocytophilum (11.8\%), Coxiella burnetii (3.2\%), and Babesia/Theileria spp. (2.1\%). Coinfection of A. phagocytophiulm and C. burnetii was detected in a camel. C. burnetii sequences from our samples showed a high phylogenetic relatedness to strains from Europe, Africa, and Asia. The study represents the first molecular investigation on tick-borne pathogens in camels from United Arabian Emirates, and it highlights the possible risk of infection for humans working in close contact with camels.

Abstract: Camels represent an important resource for inhabitants of the most arid regions of the world and their survival is mainly related to environment conditions including the risk of parasitic diseases, which may represent a significant cause of losses in livestock production of these areas. Camels may be parasitized by several hematophagous arthropods, which can be vectors of several diseases including zoonosis. This study aimed to investigate in dromedary camels and their ticks the importance of tick-borne hemoparasites that might be responsible for a recent and obscure morbidity of camels in Al Dhafra region of Abu Dhabi, UAE. Blood samples and ticks from 93 naturally infected camels belonging to 36 herds, affected by variable acute clinical syndromes lasting from 3 to 5 days, were analyzed through molecular techniques for specific DNA presence of different blood pathogens: Anaplasma marginale/Anaplasma ovis, Anaplasma phagocytophilum, Coxiella burnetii, Babesia spp., and Theileria spp. DNA. All the 72 ticks collected belonged to the Hyalomma dromedarii species and were negative for blood pathogens. $n=15$ camels $(16.1 \%)$ were found positive to the following tick-borne hemoparasites: A. phagocytophilum 11 (11.8\%), Coxiella burnetii 3 (3.2\%), and Babesia/Theileria spp. 2 (2.1\%). One singular camel showed coinfection of C. burnetii and A. phagocytophiulm. Genetic profile of $C$. burnetii showed a high phylogenetic relatedness to European, Asian and African C. burnetii strains. This is the first laboratory investigation on tick-borne pathogens in camels in UAE, and the first report of A. phagocytophilum and C. burnetii. Moreover, since the detected pathogens are 
recognized pathogens for humans, this study highlights the zoonotic risk for humans working in camel husbandry.

Keywords: dromedary camels; ticks; hemoparasites; molecular detection; phylogenetic analysis: United Arab Emirates

\section{Introduction}

The dromedary camels (Camelus dromedarius), or Arabian camels, are mostly prevalent in the arid regions from the east of Asia to the north of Africa [1] with an overall population of about 30 million animals [2]. Camels may be parasitized by several hematophagous arthropods, affecting significantly milk and meat production or causing mortality. Ticks belonging to the genera Rhipicephalus, Hyalomma, Dermacentor, Ixodes, Amblyomma, Argas, Otobius, and Ornithodoros are often reported on camels [3]. Ticks are able to transmit several zoonotic and non-zoonotic parasitic, viral, and bacterial pathogens [4]. It has been reported that several zoonotic bacteria of public health importance have previously been detected in tick populations parasitizing camels and also in the blood of camels [5]. In addition, several other studies showed a variety of pathogens infecting camels including Coxiella burnetii [6], Rickettsia spp. (R. aeschlimannii, R. africae, and R. sibirica mongolitimonae), Bartonella (B. bovis and B. rochalimae), Anaplasma phagocytophilum, Borrelia burgdorferi (sensu lato) (s.l.) [7], and Theileria spp. (T. dromedarii, T. camelensis, and T. annulata) [8-10]. Studies in neighboring countries such as Iran and Saudi Arabia have reported Theileria spp., Babesia spp., and Anaplasma spp. in camels [11-13]. Incidence of clinical theileriosis in dromedary camels have been reported in the United Arab Emirates [14]. T. annulata antigen was detected in Hyalomma dromedarii ticks in the Eastern region of Abu Dhabi [15]. In several studies, sub-clinical anaplasmosis was reported in camels, and A. camelii, A. ovis, A. platys, and A. phagocytophilum were the most prevalent pathogens in both Dromedary and Bactrian camels [16-19]. Blood parasites, mainly Theileria and Anaplasma genera, significantly affect hematological and biochemical profile of animal hosts indicating that such pathogens interfere with the hepatic, renal, and muscular functions [20,21].

Published studies on camel pathogens have focused on case reports or studies of prevalence carried out by microscopical examination of fecal samples or blood smears, whereas identification of parasites by more specific molecular biology tools is less common [5]. However, new molecular methods for diagnosis of blood pathogens have provided data on prevalence of these parasites with far greater accuracy than conventional microscopy. Moreover, considering the difficulty of protozoa or rickettsia isolation even in the most advanced veterinary diagnostic laboratories, DNA detection has taken over as the "gold standard" for the diagnosis of parasitic infections [22].

There is lack of information on hemoparasites of camels in the Middle East and their significance on health and productivity. Arid climate, abundance of tick vectors, extensive movement of livestock between neighboring countries, and lack of a large-scale integrated tick control program make the region vulnerable to tick-borne diseases causing severe economic losses to camel owners and raises implications over the human health due to the zoonotic pathogens.

In this context, the current study is aimed to detect by molecular techniques the intracellular tick-borne hemoparasites circulating in sub-clinically infected dromedary camels and related ticks in the emirates of Abu Dhabi (Al Dhafra region).

\section{Materials and Methods}

\subsection{Study Area}

Al Dhafra is one of the three regions in the Emirates of Abu Dhabi, forming the Western part of the United Arab Emirates and it represents by far the largest region by area, occupying $71 \%$ of the Emirate's total area. The Tropic of Cancer runs through the southern 
part of the Emirate, giving its climate an arid nature characterized by high temperatures throughout the year, and a very hot summer (June to August) associated with high relative humidity, especially in coastal areas (Supplementary FileSupplementary File, Figure S1).

\subsection{Targeted Animals and Sample Collection}

$N=93$ clinically infected camels from $n=36$ herds were selected for incidental investigation on tick-borne hemoparasites and other bacterial pathogens. Target animals were selected on observation of variable acute clinical signs including pyrexia, anorexia, swelling of external lymph nodes, edematous swellings, lacrimation, or nervous signs commonly observed in other ruminants infected with blood parasites. Blood samples were collected from jugular vein of 93 individual infected camels of 3 years and above ages, utilizing commercial vials (BD Vacutainer ${ }^{\circledR}$, Bristol Circle Oakville, ON, Canada) containing EDTA and, before $24 \mathrm{~h}$, taken to the Diagnostic Laboratories. Approximately, $1 \mathrm{~mL}$ blood was spotted on Whatman No. 4 filter paper, dried at room temperature, and stored at $-20{ }^{\circ} \mathrm{C}$ for further DNA extraction and analysis. Blood cells were separated from the serum by centrifugation and 70 out of the 93 samples were also investigated for hematology and chemistry profile as previously described [23]. Ticks were randomly collected from the 93 camels reared in the study area and stored at room temperature in $70 \%$ ethanol.

\subsection{Tick Species Identification}

Ticks were identified under a stereomicroscope analyzing the external morphological characteristics using morphological keys reported in literature [24].

Molecular identification has been carried out as previously described $[25,26]$. Briefly, ticks were sectioned longitudinally and one half of each tick was used for DNA extraction using the Pure link Genomic DNA Kit (Thermo Fisher ${ }^{\mathrm{TM}}$ Applied Biosystems ${ }^{\mathrm{TM}}$, Waltham, MA, USA) according to the manufacturer's instruction. The extracted DNA was quantified by Nanodrop 2000 (Thermo Fisher) and stored at $-20{ }^{\circ} \mathrm{C}$ until use.

A fragment of $360 \mathrm{bp}$ of the mitochondrial small subunit 12S rRNA gene was amplified by PCR using the primers T2A, 5'-AAATGAGAGCGACGGGCGATGT-3', and T1, 5'AAACTAGGATTAGATACCCT 3' [27]. PCR was performed in a MJ Research PTC-200 Peltier Thermal Cycler (Hampton, NH, USA). Thermal profile included an initial denaturation at $95^{\circ} \mathrm{C}$ for $15 \mathrm{~min}$, followed by 35 cycles of denaturation at $95^{\circ} \mathrm{C}$ for $30 \mathrm{~s}$, annealing at $51{ }^{\circ} \mathrm{C}$ for $30 \mathrm{~s}$, and elongation at $72{ }^{\circ} \mathrm{C}$ for $1 \mathrm{~min}$. A final extension at $72{ }^{\circ} \mathrm{C}$ for $5 \mathrm{~min}$ was performed.

\subsection{Extraction of DNA from Camels}

DNA from dried blood spots on filter papers was extracted following method previously described [28]. Briefly, under aseptically condition, dried blood spots were cut into small pieces with sterile scissors and transferred into $1.5 \mathrm{~mL}$ microtubes containing $500 \mu \mathrm{L}$ PBS; the mixtures were incubated at $37^{\circ} \mathrm{C}$ for $15 \mathrm{~min}$ and then centrifuged at $8000 \mathrm{rpm}$ for 3 min. Finally, $200 \mu$ L DNA was extracted using QIAamp DNA Mini Kit (QIAGEN, Hilden, Germany) following the manufacturer's instructions. The extracted DNA was quantified by Nanodrop 2000 (Thermo Fisher) and stored at $-20^{\circ} \mathrm{C}$ until use.

\subsection{Polymerase Chain Reaction}

Nucleic acids extracted both from 93 camels and from 72 ticks were analyzed by PCR to detect DNA of Anaplasma marginale/A. ovis [29,30], Anaplasma phagocytophilum [31], and Coxiella burnetii [32]. Primers are tabulated in the Supplementary File (Table S1).

PCR was performed using GoTaq Polymerase (Promega, Madison, WI, USA). For each reaction, a positive control, consisting of an in-house prepared reference DNA obtained from positive field samples confirmed by sequencing, and a negative control were used. PCR was performed in a MJ Research PTC-200 Peltier Thermal Cycler. For each PCR, the thermal profiles are reported in the Supplementary File (Table S1). PCR products were 
visualized under UV after electrophoretic migration on 1.5\% agarose gel containing SYBR Safe 1X (Invitrogen by @ 2021 Life Technologies Corporation, Carlsbad, CA, USA).

\subsection{Reverse Line Blot (RLB) for Babesia and Theileria spp.}

Babesia and Theileria spp. DNA was detected by Reverse Line Blot (RLB). The hypervariable V4 region of the $18 \mathrm{~S}$ rRNA gene of Babesia and Theileria species was amplified by PCR as previously described [33]. In particular, a touchdown PCR program was used in order to minimize nonspecific amplification. The protocol included $3 \mathrm{~min}$ at $94{ }^{\circ} \mathrm{C}$, two cycles of $20 \mathrm{~s}$ at $94{ }^{\circ} \mathrm{C}, 30 \mathrm{~s}$ at $67^{\circ} \mathrm{C}$, and $30 \mathrm{~s}$ at $72{ }^{\circ} \mathrm{C}$, and then two cycles with conditions identical to the previous cycles but with an annealing temperature of $65^{\circ} \mathrm{C}$. During subsequent two cycle sets, the annealing temperature was lowered by $2{ }^{\circ} \mathrm{C}$ until it reached $57^{\circ} \mathrm{C}$. Then, an additional 40 cycles each consisting of $20 \mathrm{~s}$ at $94^{\circ} \mathrm{C}, 30 \mathrm{~s}$ at $57^{\circ} \mathrm{C}$, and $20 \mathrm{~s}$ at $72{ }^{\circ} \mathrm{C}$ were performed. The PCR was ended by an extra incubation for $7 \mathrm{~min}$ at $72{ }^{\circ} \mathrm{C}$.

Reactions were carried out in $50 \mu \mathrm{L}$ with $5 \mu \mathrm{L}$ of DNA extracted from camel blood in a MJ Research PTC-200 Peltier Thermal Cycler. PCR products were then used for RLB hybridization, as described by [33-36]. Used oligonucleotide probes are reported in the Supplementary Files (Table S2). After hybridization, the membrane was exposed to a chemiluminescent detection film (GE Healthcare, Chicago, Illinois, USA) for $60 \mathrm{~min}$ to $24 \mathrm{~h}$ and then developed on Develop X-ray film (Agfa-Gevaert, Mortsel, Belgium) and fixed X-ray film (Agfa-Gevaert, Mortsel, Belgium). A black spot in the sample-probe cross in the hyper film indicated a positive signal for that pathogen.

\subsection{Sequencing}

A sequencing step was carried out for positive PCR reactions. PCR products for sequencing were purified using the Wizard SV Gel and PCR Clean-up System (Promega, Madison, WI, United States), quantified, and sent for sequencing (@ Macrogen Europe, Amsterdam, The Netherland).

The obtained sequences were analyzed for nucleotide sequence identity by comparing them with reference strains in the GenBank database using the Basic Local Alignment Search Tool (BLAST, available online at https://blast.ncbi.nlm.nih.gov/Blast.cgi? PROGRAM=blastn\&PAGE_TYPE=BlastSearch\&LINK_LOC=blasthome, accessed date 20 July 2020.

\subsection{Phylogenetic Analysis}

Multiple sequence alignments were performed using BioEdit (Ibis Biosciences, Carlsbad, CA, USA) and ClustalW version 2.0.10 (www.ebi.ac.uk/ clustalw, accessed date 3 October 2020). Phylogenetic trees were constructed by the Maximum Likelihood and the Neighbor-joining [37] methods. The evolutionary distances were computed using the Kimura 2-parameter [38] method, as implemented in the Mega 7 package [39] deleting all the gap sites. Since sequences of Coxiella endosymbionts have been previously documented in UAE in Argasid ticks collected from seabirds [40], we included Coxiella endosymbionts sequences to investigate their phylogenetic relationship. Legionella pneumophila was included as outgroups. GenBank accession numbers of sequences used for phylogenetic analysis are reported in Table 1. 
Table 1. GenBank accession numbers of sequences used for phylogenetic analysis ${ }^{1}$.

\begin{tabular}{|c|c|c|c|}
\hline Organism & Host & Country & GenBank Accession Number \\
\hline C. burnetii & Homo sapiens & Russia & MK335933.1 \\
\hline C. burnetii & Amblyomma variegatum & Nigeria & $\begin{array}{l}\text { JQ346185.1 } \\
\text { JQ346188 }\end{array}$ \\
\hline C. burnetii & Hyalomma impeltatum & Tunisia & MK416231.1 \\
\hline C. burnetii & Cattle & China & MK345478.1 \\
\hline C. burnetii & Rhipicephalus evertsi evertsi & South Africa & MH751472.1 \\
\hline C. burnetii & Panthera leo & Italy & EF547935.1 \\
\hline C. burnetii & Ixodes ricinus & Belarus & JQ711247.1 \\
\hline C. burnetii & Dermacentor reticulatus & Slovakia & MG860513.1 \\
\hline C. burnetii & Sheep & France & EU888864.1 \\
\hline C. burnetii & Cattle & France & EU888861.1 \\
\hline C. burnetii & Goat & France & EU888862.1 \\
\hline $\begin{array}{c}\text { Coxiella endosymbiont of } \\
\text { Argas monachus }\end{array}$ & Argas monachus & Argentina & KР985445.1 \\
\hline $\begin{array}{c}\text { Coxiella endosymbiont of } \\
\text { Argas persicus }\end{array}$ & Argas persicus & Iran & MF370854.1 \\
\hline $\begin{array}{c}\text { Coxiella endosymbiont of } \\
\text { Ornithodoros capensis }\end{array}$ & Ornithodoros capensis & France & KP985451.1 \\
\hline $\begin{array}{l}\text { Coxiella endosymbiont of } \\
\text { Ornithodoros amblus }\end{array}$ & Ornithodoros amblus & Peru & KP985447.1 \\
\hline $\begin{array}{l}\text { Coxiella endosymbiont of } \\
\text { Haemaphysalis punctata }\end{array}$ & Haemaphysalis punctata & England & KP985492.1 \\
\hline Uncultured Coxiella sp. & Ornithodoros capensis sensu lato & Chile & KJ459055.1 \\
\hline $\begin{array}{l}\text { Coxiella endosymbiont of } \\
\text { Amblyomma cajennense }\end{array}$ & Amblyomma cajennense & Brazil & KР985482.1 \\
\hline $\begin{array}{l}\text { Coxiella endosymbiont of } \\
\text { Rhipicephalus decoloratus }\end{array}$ & Rhipicephalus decoloratus & South Africa & KY678192.1 \\
\hline
\end{tabular}

${ }^{1}$ Date of accession to the GenBank database 2 October 2020.

\subsection{Statistical Analysis}

Statistical analysis was performed using chi-square function in R software, version 4.0.4 [41] and Bonferroni correction was applied. Prevalence differences between the tick-borne hemoparasites detected inside the sample was tested. Value of $p<0.016$ was considered significant.

\section{Results}

\subsection{Hematology Profile}

A total of 70 out of 93 camel blood samples were subjected to complete blood count (CBC). The most relevant hematological findings were neutrophilia 78.6\% (55 samples), lymphopenia $75.7 \%$ (53 samples), and monocytosis 35.7 \% (25 samples). Moreover, 57 samples $(81.4 \%)$ showed a marked increase in heart and muscle creatine kinase enzyme (CK), 60 samples $(85.7 \%)$ showed high values of hepatic and muscular enzymes aspartate transaminase (AST) and lactate dehydrogenase (LDH), while liver enzyme gamma-glutamyl transferase (GGT) showed variable results such as for other standard camel hematology parameters. 


\subsection{Tick-Borne Pathogens}

All the 72 ticks collected from camels, as confirmed by both morphological and molecular methods, belonged to the Hyalomma dromedarii species. All the ticks resulted negative for all the hemoparasites investigated in the present study.

Out of the 93 examined blood samples coming from dromedarian camels, $n=15$ (16.1\%) were found positive to tick-borne hemoparasites (Table 2$), n=11(11.8 \%)$ were positive to A. phagocytophilum, and three camels were positive to C. burnetii (3.2\%). Coinfection of A. phagocytophiulm and C. burnetii was also detected in one camel. All the samples were negative to Anaplasma marginale/A. ovis. Reverse Line Blot detected two camels positive to Babesia spp./Theileria spp. 2 (2.1\%). Significant statistical difference between the three tick-borne hemoparasites detected (A. phagocytophilum, C. burnetii, and Babesia/Theileria spp.) was observed $(p<0.016)$.

Table 2. Results of molecular investigation on dromedary camels.

\begin{tabular}{|c|c|}
\hline Investigation on Dromedarian Camels & Overall \\
\hline Analyzed dromedarian camels & 93 \\
\hline TBPs Prevalence & $16.1 \%$ * \\
\hline \multicolumn{2}{|l|}{ Anaplasma marginale/A. ovis } \\
\hline Prevalence & 0 \\
\hline \multicolumn{2}{|l|}{ Anaplasma phagocytophilum } \\
\hline Prevalence & $11.8 \%$ \\
\hline \multicolumn{2}{|l|}{ Coxiella burnetii } \\
\hline Prevalence & $3.2 \%$ \\
\hline Babesia/Theileria spp. & \\
\hline Prevalence & $2.1 \%$ \\
\hline
\end{tabular}

* Coinfection of A. phagocytophiulm and C. burnetii was detected in a camel.

Their DNA reacted with the probes of Babesia spp./Theileria spp., Babesia sp.1, Theileria sp. 1, and Theileria sp. 2 but with no other specie-specific probes in the membrane.

The products of PCRs for A. phagocytophilum and Babesia spp./Theileria spp. were too weak for visualization and did not allow to obtain sequences of good quality. Sequences obtained from the C. burnetii-positive samples were submitted to GenBank with the following accession numbers: MW057691, MW057692, and MW057693, respectively. Our sequences showed 100\% identity among them and shared between $99.7 \%$ and $100 \%$ nucleotide sequence identities with sequences previously reported in GenBank (JQ346185 and MK335933.1, respectively).

\subsection{Phylogenetic Analysis}

C. burnetii obtained sequences were used for phylogenetic analysis (Figure 1). The inferred evolutionary history indicated that our sequences were classified in a single C. burnetii clade with sequences from Slovakia (MG860513.1), Belarus (JQ711247.1), Italy (EF547935.1), Nigeria (JQ346185.1), Tunisia (MK416231.1), and China (MK345478.1). Different clades were obtained with Coxiella endosymbiont sequences from different countries. 


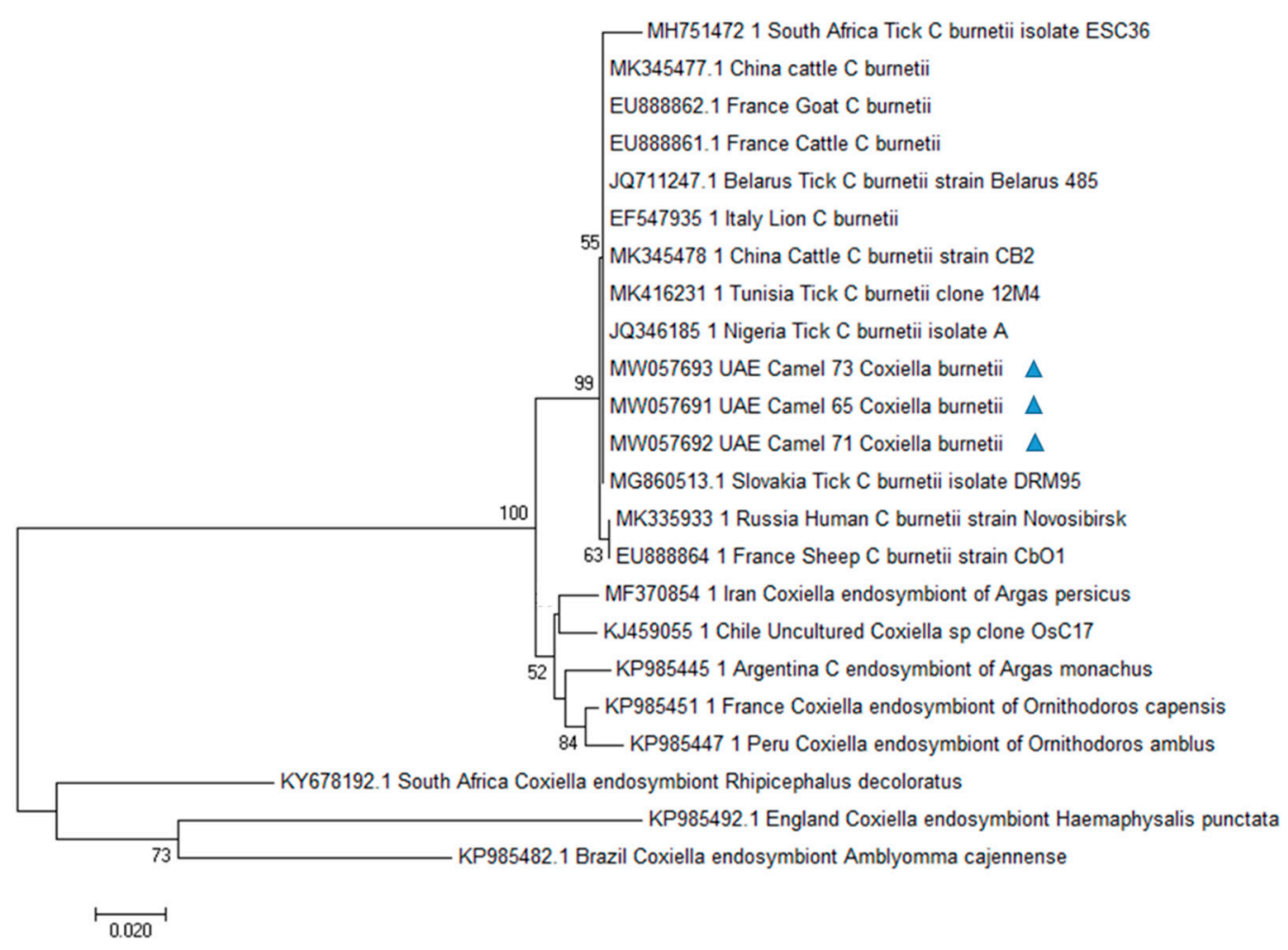

Figure 1. Phylogenetic analysis of Coxiella burnetii htpB gene sequences by Neighbor-Joining method based on the Kimura 2-parameter model. Evolutionary analyses were conducted in MEGA7. Numbers at nodes represent percentage occurrence in 1000 bootstrap replication. Sequences from this study are marked with triangle. The value lower than $50 \%$ are hidden.

\section{Discussion}

Investigation of blood samples and ticks collected from naturally infected camels from different herds in Al Dhafra region of Abu Dhabi using molecular techniques enabled detection of DNA of tick-borne pathogens identified as A. phagocytophilum, Coxiella burnetii, and Babesia/Theileria spp. The main hematological and biochemical findings of this study were an increased WBC count as well as increase in heart, muscle, and liver enzymes indicating potential damage to cells of these organs. Similar profiles have been previously observed in camels suffering blood parasitic infections [20,21].

Data on identification of the tick population of Al Dhafra region confirmed previous studies on prevalence reporting that $\mathrm{Hy}$. dromedarii is the main species parasitizing dromedary camels [42]. In this study, we did not find positive ticks to the examined pathogens, suggesting a limited risk of exposure through tick bites. Further studies are needed in order to get a more complete epidemiological picture of the area, enrolling more farms for a larger study of the camel population of UAE.

Nevertheless, the risk of health and welfare of the infested animals cannot be overlooked due to vector potential of $\mathrm{Hy}$. dromedarii towards a high number of emerging and re-emerging pathogens, some of which also are zoonotic agents. Indeed, this tick species is considered the principal vector of Theileria spp. of domestic and wild ungulates in the Arabian Peninsula [42]. Hy. dromedarii has been confirmed to have a role in the transmission of Rickettsia, Francisella, and C. burnetii [43], and it is also a recognized vector of Crimean-Congo hemorrhagic fever virus [44].

The absence of detection of Babesia spp. and Theileria spp. DNA in the collected ticks is consistent with the low prevalence of these pathogens reported by previous studies carried out on tick-borne diseases of camels $[15,42,45]$.

Hy. dromedarii could be also considered as potential vector in maintaining the endemism of $C$. burnetii in nature but not essential for its natural cycle and endemism maintenance in livestock. 
Indeed, C. burnetii can be transmitted through inhalation of contaminated aerosols from amniotic fluid, placenta, or contaminated wool or by direct consumption of placentas or milk from infected animals [46].

To the best of our knowledge, this is the first report of A. phagocytophilum among naturally infected dromedaries in the study area. The result is even more important considering the zoonotic potential of this pathogen also because of its role as causative agent for human granulocytic anaplasmosis. Other reports of Anaplasmataceae in the Camelus dromedarius have been described elsewhere [47].

A study on C. dromedarius in Morocco, using PCR targeting the gene groEL and further sequence analysis of positive samples, revealed 100\% identity with "Candidatus Anaplasma camelii." Phylogenetic investigation and genetic characterization confirmed high similarity with $A$. platys [48]. Anaplasma camelii infection was also reported in healthy camels in Iran [16]. Dromedary camels were thought to be a reservoir for Anaplasma phagocytophilum as stated by Bahrami et al. [19]. Unidentified species belonging to family Anaplasmataceae were reported from EDTA whole-blood samples of dromedary camels, cattle, sheep, and desert foxes in Taif district, Kingdom of Saudi Arabia, when screened using PCR targeting $16 S$ rRNA gene [12].

The present study reports for the first time the presence of $C$. burnetii DNA in camels in UAE. The htpB gene has previously been used for the detection of Coxiella organisms as well as for phylogenetic analyses $[49,50]$. HtpB sequences obtained in this study showed a high genetic relatedness with the ones of C. burnetii strains previously documented in Europe (Slovakia, Belarus Italy), Africa (Nigeria, Tunisia), and Asia (China), as supported by high bootstrap values. In UAE, Coxiella burnetii-like endosymbionts have been previously documented in Argasid ticks collected from seabirds [40]. Phylogenetic analysis carried out in that study showed that the reported Coxiella-like endosymbionts were in a separate cluster and not belonging to the $C$. burnetii group. In particular, the strain obtained from the argasid tick was closest neighbor to a Coxiella symbiont of Ornithodoros (Carios) capensis. A different molecular target, the isocitrate dehydrogenasegene, has been used for Coxiella sp. molecular characterization in that study, so that we could not include those sequences in our analysis. However, different htpB sequences from several endosymbiont Coxiella strains, including the sequence of a Coxiella endosymbiont of Ornithodoros capensis, have been processed in our phylogenetic analysis. Sequences from our samples were in a separate cluster from the above cited organisms, among the C. burnetii group and this topology of the Neighbor-Joining tree was supported by good bootstrap values.

This finding does not seem to support the same origin between the pathogen from ticks on seabirds and on camels. Further studies are thus required to better characterize the putative hosts and vectors of $C$. burnetii in UAE.

The detection of this pathogen DNA in three of the screened camels indicates the circulation of an abortion-causing pathogen that may have also implications on human health, being a zoonotic agent responsible for $Q$ fever [51,52]. Several serological studies on Coxiella burnetii have been carried out in camels in several countries, reporting a seroprevalence of 40.7\% in Egypt [53], 28.7\% in Iran [54], 46\% in Kenya [55], and 73\% in Chad [56]. Studies based on molecular detection of C. burnetii DNA in camels are less frequent. A study on reproductive disorders in dromedary camel herds carried out in Saudi Arabia detected pathogen DNA by RT-PCR in 36\% of uterine swabs collected from camels having a history of reproduction failure, representing the first association with reproductive disorders in dromedary camel herds [57].

The RLB analysis in this study reported two camels positive to Babesia spp. and Theileria spp. Their PCR products hybridized with the probes Cath all, Babesia sp.1, Theileria sp. 1 , and Theileria sp. 2 and with no other specie-specific probe in the membrane, suggesting a different species from those present in the assay, although it was not possible to confirm this result with sequencing. Previous studies reported Babesia spp. DNA in the blood of $74.5 \%$ of the camels in the Eastern region of the Sudan [58]. An epidemiological study 
on the occurrence of blood parasitic infection in camels in Northern West Coastal zone of Egypt identified Theileria, Anaplasma, Trypanosoma, and Babesia by microscopy and PCR [22].

Microscopic examination of blood samples collected from camels in South of Iraq revealed the presence of Babesia spp. and Theileria spp. in camels at percentage of $9.95 \%$ and $5.8 \%$, respectively. Molecular diagnosis based on PCR targeting 18S rRNA identified the pathogens as B. caballi and T. equi using specific primers [59]. A survey carried out in 200 peripheral blood samples from asymptomatic one-humped camels in Central and SouthEastern Iran, revealed one positive sample by PCR for Theileria annulata and Trypanosoma evansi. Sequence analysis confirmed $100 \%$ identity to T. annulata isolates from cattle [11]. Abdelwahab and colleagues [14] reported coinfection of salmonellosis and theileriosis in camels in UAE that clinically suffered from acute febrile disease with severe hematuria.

\section{Conclusions}

Camels represent a significant reservoir for zoonotic disease transmission to humans due to increased consumption and contact with camel meat and milk [60]. Our findings strongly support the need to carry out integrated strategy for animal diseases surveillance and prevention/control programs. In particular, the role of camels as hosts for zoonotic pathogens needs to be better investigated in order to understand the risk of zoonotic diseases, particularly, for humans working in close contact with camels or their products.

The major limitations of this study were the small number of samples collected and analyzed and the lack of good-quality sequences for A. phagocytophilum and Babesia spp./Theileris spp. Further studies involving a greater number of heads, herds, and ticks over a larger area of the UAE should be carried out in order to have a more accurate view of the prevalence of tick-borne pathogens and of the actual risk of disease for both animals and humans working in contact with camels in this country.

Supplementary Materials: The following are available online at https://www.mdpi.com/2076-2 $615 / 11 / 3 / 666 / s 1$, Table S1. PCR primers and amplification profiles. Table S2. Primers and Probes used for RLB targeting the V4 hypervariable region $18 \mathrm{~S}$ rRNA of Babesia and Theileria species. Figure S1. Map of United Arab Emirates (UAE) showing in red color the location of Al Dhafra Region (the study area) in the Emirate of Abu Dhabi.

Author Contributions: Conceptualization, A.T., S.S.A.M., and G.R.L.; investigation E.T.A.E.T.-A., G.E.A., V.B., F.L.R., S.M., and Z.M.A.H.; data curation, S.H. and M.A.A.; formal analysis, S.S.A.M., S.H., M.A.A., and A.I.K.; validation, S.H.; writing—original draft, V.B., E.T.A.E.T.-A., and G.E.A.; writing-review and editing, V.B., E.T.A.E.T.-A., and S.S.A.M.; funding acquisition, S.S.A.M. and G.R.L.; supervision, S.S.A.M. and G.R.L. All authors have read and agreed to the published version of the manuscript.

Funding: This research was funded by the OIE Twinning project: Twinning project between the OIE Reference Laboratories of the Italian Istituti Zooprofilattici Sperimentali (IZSLER, IZSSI, IZSAM), the Abu Dhabi Agriculture and Food Safety Authority (ADAFSA) and by the Italian Ministry of Health RC IZSSI 20/16 and 07/18.

Institutional Review Board Statement: The study did not involve any animal experiments. Blood and tick samples were taken from camels suspected of tick-borne disease. Blood sampling was necessary in order to perform laboratory analysis and did not involve any suffering of the animals sampled.

Data Availability Statement: The data presented in this study are available on request from the corresponding author.

Acknowledgments: We thank Asma Abdi Mohamed Shah, Section Manager, Pathology and Sample Management, Veterinary Laboratories Division, ADAFSA, for necessary arrangement for providing samples and Hassan Zackaria Ali Ishaq for his valuable comments in manuscript revision.

Conflicts of Interest: Authors declare that they have no competing interests. 


\section{References}

1. Ali, A.; Baby, B.; Vijayan, R. From Desert to Medicine: A Review of Camel Genomics and Therapeutic Products. Front. Genet. 2019, 10, 17. [CrossRef] [PubMed]

2. Zhu, S.; Zimmerman, D.; Deem, S.L. A Review of Zoonotic Pathogens of Dromedary Camels. EcoHealth 2019, 16, 356-377. [CrossRef] [PubMed]

3. Wernery, U.; Kinne, J.; Schuster, R.K. Camelid Infectious Disorders; World Organisation for Animal Health (OIE): Paris, France, 2014.

4. Torina, A.; Villari, S.; Blanda, V.; Vullo, S.; La Manna, M.P.; Azgomi, M.S.S.; Di Di Liberto, D.; De La Fuente, J.; Sireci, G. Innate Immune Response to Tick-Borne Pathogens: Cellular and Molecular Mechanisms Induced in the Hosts. Int. J. Mol. Sci. 2020, 21, 5437. [CrossRef] [PubMed]

5. Sazmand, A.; Joachim, A.; Otranto, D. Zoonotic parasites of dromedary camels: So important, so ignored. Parasit. Vectors 2019, 12, 1-10. [CrossRef]

6. Loftis, A.D.; Reeves, W.K.; Szumlas, D.E.; Abbassy, M.M.; Helmy, I.M.; Moriarity, J.R.; Dasch, G.A. Rickettsial agents in Egyptian ticks collected from domestic animals. Exp. Appl. Acarol. 2006, 40, 67-81. [CrossRef] [PubMed]

7. Sazmand, A.; Harl, J.; Eigner, B.; Hodžić, A.; Beck, R.; Hekmatimoghaddam, S.; Mirzaei, M.; Fuehrer, H.-P.; Joachim, A. Vectorborne bacteria in blood of camels in Iran: New data and literature review. Comp. Immunol. Microbiol. Infect. Dis. 2019, 65, 48-53. [CrossRef]

8. OIE Manual of Diagnostic Tests and Vaccines for Terrestrial Animals. 2018. Available online: https://www.oie.int/standardsetting/terrestrial-manual/access-online/ (accessed on 23 February 2021).

9. Nassar, A. Theileria infection in camels (Camelus dromedarius) in Egypt. Vet. Parasitol. 1992, 43, 147-149. [CrossRef]

10. Osman, F.; Abdelsalam, M.; Mustafa, H. Some Studies on Prevalence and Effect of Thieleria Infection on Erythrocytes Profile in Camel in Some Localities at New-Valley, Governorate, Egypt. J. Anim. Sci. Adv. 2015, 5, 1238-1244. [CrossRef]

11. Sazmand, A.; Eigner, B.; Mirzaei, M.; Hekmatimoghaddam, S.H.; Harl, J.; Duscher, G.G.; Fuehrer, H.-P.; Joachim, A. Molecular Identification of Hemoprotozoan Parasites in Camels (Camelus dromedarius) of Iran. Iran. J. Parasitol. 2016, 11, 568-573.

12. Ghafar, M.W.; Shobrak, M.Y. Molecular detection and characterization of Anaplasma phagocytophilum, the causative agent of human granulocytic anaplasmosis, in some animals suspected to be competent reservoirs in Taif district, Kingdom of Saudi Arabia. Life Sci. J. 2014, 11, 63-69.

13. Swelum, A.A.; Ismael, A.B.; Khalaf, A.F.; Abouheif, M.A. Clinical and laboratory findings associated with naturally occurring babesiosis in dromedary camels. Bull. Vet. Inst. Pulawy 2014, 58, 229-233. [CrossRef]

14. Abdelwahab, G.E.; Tigani-Asil, E.; Yusof, M.F.; Abdullah, Z.S.; Rifat, J.F.; Al Hosani, M.A.; AlMuhairi, S.S.; Khalafalla, A.I. Salmonella enterica and Theileria co-infection in dromedary camels (Camelus dromedarius) in UAE. Open Vet. J. 2019, 9, $263-268$. [CrossRef] [PubMed]

15. Al-Deeb, M.A.; Bin Muza_ar, S.; Abu-Zeid, Y.A.; Enan, M.R.; Karim, S. First record of a spotted fever group Rickettsia sp. and Theileria annulata in Hyalomma dromedarii (Acari: Ixodidae) ticks in the United Arab Emirates. Fla. Entomol. 2015, 98, 135-139. [CrossRef]

16. Sharifiyazdi, H.; Jafari, S.; Ghane, M.; Nazifi, S.; Sanati, A. Molecular investigation of Anaplasma and Ehrlichia natural infections in the dromedary camel (Camelus dromedarius) in Iran. Comp. Haematol. Int. 2016, 26, 99-103. [CrossRef]

17. Noaman, V. Molecular Detection of Novel Genetic Variants Associated to Anaplasma ovis among Dromedary Camels in Iran. Arch. Razi Inst. 2017, 73, 11-18. [PubMed]

18. Li, Y.; Yang, J.; Chen, Z.; Qin, G.; Li, Y.; Li, Q.; Liu, J.; Liu, Z.; Guan, G.; Yin, H.; et al. Anaplasma infection of Bactrian camels (Camelus bactrianus) and ticks in Xinjiang, China. Parasit. Vectors 2015, 8, 1-6. [CrossRef] [PubMed]

19. Bahrami, S.; Hamidinejat, H.; Tafreshi, A.R.G. First molecular detection of Anaplasma phagocytophilum in dromedaries (Camelus dromedarius). J. Zoo Wildl. Med. 2018, 49, 844-848. [CrossRef] [PubMed]

20. Ismael, A.B.; Swelum, A.A.; Khalaf, A.F.; Abouheif, M.A. Clinical, haematological and biochemical alterations associated with an outbreak of theileriosis in dromedaries (Camelus dromedarius) in Saudi Arabia. Pak. Vet. J. 2014, 34, $209-213$.

21. Al Obaidi, Q.T.; Hasan, S.D.; Alsaad, K.M. Clinical haematological and biochemical parameters in Arabian one-humped camels (Camelus dromedarius) with Babesia caballi infection. Bulg. J. Vet. Med. 2019. [CrossRef]

22. El-Naga, T.R.A.; Barghash, S.M. Blood Parasites in Camels (Camelus dromedarius) in Northern West Coast of Egypt. J. Bacteriol. Parasitol. 2016, 7, 258. [CrossRef]

23. Thrall, M.A.; Weiser, G.; Allison, R.; Camppbell, T. Veterinary Haematology and Clinical Chemistry, 2nd Ed. ed; Wiley-Blackwell: Hoboken, NJ, USA, 2012.

24. Walker, A.R.; Bouattour, A.; Camicas, J.L.; Estrada-Peña, A.; Horak, I.G.; Latif, A.A.; Pegram, R.G.; Preston, P.M. Ticks of Domestic Animals in Africa: A Guide to Identification of Species; Bioscience Reports: Edinburgh, UK, 2014; pp. 74-217.

25. De Mera, I.G.F.; Blanda, V.; Torina, A.; Dabaja, M.F.; El Romeh, A.; Cabezas-Cruz, A.; De La Fuente, J. Identification and molecular characterization of spotted fever group rickettsiae in ticks collected from farm ruminants in Lebanon. Ticks Tick-borne Dis. 2018, 9 , 104-108. [CrossRef] [PubMed]

26. Dabaja, M.F.; Tempesta, M.; Bayan, A.; Vesco, G.; Greco, G.; Torina, A.; Blanda, V.; La Russa, F.; Scimeca, S.; Ezzedine, M.; et al. Diversity and distribution of ticks from domestic ruminants in Lebanon. Vet. Ital. 2017, 53, 147-155. 
27. Beati, L.; Keirans, J.E. Analysis of the Systematic Relationships among Ticks of the Genera Rhipicephalus and Boophilus (Acari: Ixodidae) Based on Mitochondrial 12S Ribosomal DNA Gene Sequences and Morphological Characters. J. Parasitol. 2001, 87, 32-48. [CrossRef]

28. Choi, E.-H.; Lee, S.K.; Ihm, C.; Sohn, Y.-H. Rapid DNA Extraction from Dried Blood Spots on Filter Paper: Potential Applications in Biobanking. Osong Public Health Res. Perspect. 2014, 5, 351-357. [CrossRef] [PubMed]

29. De La Fuente, J.; Bussche, R.A.V.D.; Prado, T.M.; Kocan, K.M. Anaplasma marginale msp1 Genotypes Evolved under Positive Selection Pressure but Are Not Markers for Geographic Isolates. J. Clin. Microbiol. 2003, 41, 1609-1616. [CrossRef] [PubMed]

30. Torina, A.; Agnone, A.; Blanda, V.; Alongi, A.; D'Agostino, R.; Caracappa, S.; Marino, A.M.; Di Marco, V.; de la Fuente, J. Development and validation of two PCR tests for the detection of and differentiation between Anaplasma ovis and Anaplasma marginale. Ticks Tick-borne Dis. 2012, 3, 283-287. [CrossRef] [PubMed]

31. De La Fuente, J.; Massung, R.F.; Wong, S.J.; Chu, F.K.; Lutz, H.; Meli, M.; Von Loewenich, F.D.; Grzeszczuk, A.; Torina, A.; Caracappa, S.; et al. Sequence Analysis of the msp4 Gene of Anaplasma phagocytophilum Strains. J. Clin. Microbiol. 2005, 43, 1309-1317. [CrossRef]

32. To, H.; Kako, N.; Zhang, G.Q.; Otsuka, H.; Ogawa, M.; Ochiai, O.; Nguyen, S.V.; Yamaguchi, T.; Fukushi, H.; Nagaoka, N.; et al. Q fever pneumonia in children in Japan. J. Clin. Microbiol. 1996, 34, 647-651. [CrossRef] [PubMed]

33. Nagore, D.; Garía-Sanmartín, J.; Garía-Pérez, A.L.; Juste, R.A.; Hurtado, A. Identification, genetic diversity and prevalence of Theileria and Babesia species in a sheep population from Northern Spain. Int. J. Parasitol. 2004, 34, 1059-1067. [CrossRef]

34. Georges, K.; Loria, G.; Riili, S.; Greco, A.; Caracappa, S.; Jongejan, F.; Sparagano, O. Detection of haemoparasites in cattle by reverse line blot hybridisation with a note on the distribution of ticks in Sicily. Vet. Parasitol. 2001, 99, 273-286. [CrossRef]

35. Gubbels, J.M.; De Vos, A.P.; Van Der Weide, M.; Viseras, J.; Schouls, L.M.; De Vries, E.; Jongejan, F. Simultaneous Detection of BovineTheileria and Babesia Species by Reverse Line Blot Hybridization. J. Clin. Microbiol. 1999, 37, 1782-1789. [CrossRef] [PubMed]

36. Schnittger, L.; Yin, H.; Qi, B.; Gubbels, M.J.; Beyer, D.; Niemann, S.; Jongejan, F.; Ahmed, J.S. Simultaneous detection and differentiation of Theileria and Babesia parasites infecting small ruminants by reverse line blotting. Parasitol. Res. 2004, 92, 189-196. [CrossRef] [PubMed]

37. Saitou, N.; Nei, M. The neighbor-joining method: A new method for reconstructing phylogenetic trees. Mol. Biol. Evol. 1987, 4, 406-425. [CrossRef] [PubMed]

38. Kimura, M. A simple method for estimating evolutionary rates of base substitutions through comparative studies of nucleotide sequences. J. Mol. Evol. 1980, 16, 111-120. [CrossRef] [PubMed]

39. Kumar, S.; Stecher, G.; Tamura, K. MEGA7: Molecular Evolutionary Genetics Analysis Version 7.0 for Bigger Datasets. Mol. Biol. Evol. 2016, 33, 1870-1874. [CrossRef] [PubMed]

40. Al-Deeb, M.A.; Frangoulidis, D.; Walter, M.C.; Kömpf, D.; Fischer, S.F.; Petney, T.; Bin Muzaffar, S. Coxiella-like endosymbiont in argasid ticks (Ornithodoros muesebecki) from a Socotra Cormorant colony in Umm Al Quwain, United Arab Emirates. Ticks Tick-borne Dis. 2016, 7, 166-171. [CrossRef]

41. R Core Team. R: A Language and Environment for Statistical Computing. R Foundation for Statistical Computing: Vienna. 2018. Available online: https:/ / www.R-project.org (accessed on 23 February 2021).

42. Alanazi, A.D.; Nguyen, V.L.; Alyousif, M.S.; Manoj, R.R.S.; Alouffi, A.S.; Donato, R.; Sazmand, A.; Mendoza-Roldan, J.A.; Dantas-Torres, F.; Otranto, D. Ticks and associated pathogens in camels (Camelus dromedarius) from Riyadh Province, Saudi Arabia. Parasit. Vectors 2020, 13, 1-9. [CrossRef]

43. Abdullah, H.H.A.M.; El-Shanawany, E.E.; Abdel-Shafy, S.; Abou-Zeina, H.A.A.; Abdel-Rahman, E.H. Molecular and immunological characterization of Hyalomma dromedarii and Hyalomma excavatum (Acari: Ixodidae) vectors of Q fever in camels. Vet. World 2018, 11, 1109-1119. [CrossRef] [PubMed]

44. Gargili, A.; Estrada-Peña, A.; Spengler, J.R.; Lukashev, A.; Nuttall, P.A.; Bente, D.A. The role of ticks in the maintenance and transmission of Crimean-Congo hemorrhagic fever virus: A review of published field and laboratory studies. Antivir. Res. 2017, 144, 93-119. [CrossRef]

45. Alan, A.D.; Abdullah, S.; Helps, C.; Wall, R.; Puschendor, R.; Alharbi, S.A.; Abdel-Shaf, S.; Shaapan, R.M. Tick-Borne Pathogens in Ticks and Blood Samples Collected from Camels in Riyadh Province, Saudi Arabia. Int. J. Zool. Res. 2017, 14, 30-36. [CrossRef]

46. Angelakis, E.; Raoult, D. Q fever. Vet. Microbiol. 2010, 140, 297-309. [CrossRef]

47. Ben Said, M.; Selmi, R.; Rhouma, M.H.; Belkahia, H.; Messadi, L. Molecular phylogeny and genetic diversity based on msp1a, groEL and gltA genes of Anaplasma ovis Tunisian isolates compared to available worldwide isolates and strains. Ticks Tick-borne Dis. 2020, 11, 101447. [CrossRef] [PubMed]

48. Lbacha, H.A.; Zouagui, Z.; Alali, S.; Rhalem, A.; Petit, E.; Ducrotoy, M.J.; Boulouis, H.-J.; Maillard, R. “Candidatus anaplasma camelii" in one-humped camels (Camelus dromedarius) in Morocco: A novel and emerging Anaplasma species? Infect. Dis. Poverty 2017, 6, 1-8. [CrossRef]

49. Fournier, P.-E.; Raoult, D. Comparison of PCR and Serology Assays for Early Diagnosis of Acute Q Fever. J. Clin. Microbiol. 2003, 41, 5094-5098. [CrossRef] [PubMed]

50. Li, Y.; Wen, X.; Li, M.; Moumouni, P.F.A.; Galon, E.M.; Guo, Q.; Rizk, M.A.; Liu, M.; Li, J.; Ji, S.; et al. Molecular detection of tick-borne pathogens harbored by ticks collected from livestock in the Xinjiang Uygur Autonomous Region, China. Ticks Tick-borne Dis. 2020, 11, 101478. [CrossRef] [PubMed] 
51. Eldin, C.; Mélenotte, C.; Mediannikov, O.; Ghigo, E.; Million, M.; Edouard, S.; Mege, J.-L.; Maurin, M.; Raoult, D. From Q Fever to Coxiella burnetii Infection: A Paradigm Change. Clin. Microbiol. Rev. 2017, 30, 115-190. [CrossRef] [PubMed]

52. Verso, M.G.; Vesco, G.; Villari, S.; Galluzzo, P.; Gargano, V.; Matranga, D.; De Marchis, P.; Picciotto, D. Analysis of seroprevalence against Coxiella burnetii in a sample of farm workers in Western Sicily. Ann. Agric. Environ. Med. 2015, $23,71-74$. [CrossRef] [PubMed]

53. Klemmer, J.; Njeru, J.; Emam, A.; El-Sayed, A.; Moawad, A.A.; Henning, K.; Elbeskawy, M.A.; Sauter-Louis, C.; Straubinger, R.K.; Neubauer, H.; et al. Q fever in Egypt: Epidemiological survey of Coxiella burnetii specific antibodies in cattle, buffaloes, sheep, goats and camels. PLoS ONE 2018, 13, e0192188. [CrossRef]

54. Pirouz, H.J.; Mohammadi, G.; Mehrzad, J.; Azizzadeh, M.; Shirazi, M.H.N. Seroepidemiology of Q fever in one-humped camel population in northeast Iran. Trop. Anim. Heal. Prod. 2015, 47, 1293-1298. [CrossRef]

55. DePuy, W.; Benka, V.; Massey, A.; Deem, S.L.; Kinnaird, M.; O’Brien, T.; Wanyoike, S.; Njoka, J.; Butt, B.; Foufopoulos, J.; et al. Q Fever Risk Across a Dynamic, Heterogeneous Landscape in Laikipia County, Kenya. EcoHealth 2014, 11, 429-433. [CrossRef] [PubMed]

56. Chelling, E.; Diguimbaye, C.; Daoud, S.; Nicolet, J.; Boerlin, P.; Tanner, M.; Zinsstag, J. Brucellosis and Q-fever seroprevalences of nomadic pastoralists and their livestock in Chad. Prev. Vet. Med. 2003, 61, 279-293. [CrossRef] [PubMed]

57. Khalafalla, A.I.; Al Eknah, M.M.; Abdelaziz, M.; Ghoneim, I.M. A study on some reproductive disorders in dromedary camel herds in Saudi Arabia with special references to uterine infections and abortion. Trop. Anim. Heal. Prod. 2017, 49, 967-974. [CrossRef] [PubMed]

58. Ibrahim, A.M.; Kadle, A.A.H.; Nyingilili, H.S. Microscopic and Molecular Detection of Camel Piroplasmosis in Gadarif State, Sudan. Veter-Med. Int. 2017, 2017, 1-5. [CrossRef] [PubMed]

59. Jasim, H.J.; Azzal, G.Y.; Othman, R.M. Conventional and molecular detection of Babesia caballi and Theileria equi parasites in infected camels in south of Iraq. Basra J. Vet. Res. 2015, 14, 110-121.

60. Wernery, U.; Kaaden, O. Infectious Diseases of Camelids; Blackwell Science Inc.: London, UK, 2002; pp. 99-116. 